\title{
Approaches to Addressing Informal Settlement Problems: A Case Study of District 13 in Kabul, Afghanistan
}

\author{
Maqsood Rezayee ${ }^{1}$, Gabriel Hoh Teck Ling ${ }^{1} \&$ Siti Hajar Misnan ${ }^{1}$ \\ ${ }^{1}$ Department of Urban and Regional Planning, Faculty of Built Environment and Surveying, Universiti Teknologi \\ Malaysia
}

Correspondence: Maqsood Rezayee, Department of Urban and Regional Planning, Faculty of Built Environment and Surveying, Universiti Teknologi Malaysia. Dasht-E-Barchi, District 13, Kabul, 1001, Afghanistan. Tel: 93797-328-619. E-mail: mqsoodrezay@yahoo.com

Received: January 13, 2020

Accepted: February 18, 2020 Online Published: February 20, 2020

doi:10.5539/emr.v9n1p1

URL: https://doi.org/10.5539/emr.v9n1p1

\begin{abstract}
Afghanistan witnessed rapid urbanization in recent decades due to the post-war recovery process. When the war ended in 2001 with the fall of Taliban regime, most Afghan refugees returned to urban areas of Afghanistan, especially in Kabul. Moreover, the rapid urbanization, migration from rural areas, and population growth impacted Kabul with the manifestation of informal settlement. The residents of informal settlements suffer social and economic exclusion from the benefits and opportunities of an urban environment. Furthermore, the residents of informal settlements experience disadvantages such as geographical marginalization, shortage of basic infrastructure, improper governance framework, vulnerability to the effect of poor environment, and natural disasters. With all the above, the problems of informal settlements are considered enormous challenges for informal residents. Therefore, this paper aims to identify the proper approaches to addressing informal settlement problems in District 13 of Kabul. To reach the aim of the research, the interview and questionnaires survey were used as instrument in data collection. The finding of this paper indicates that through the resident's preferences, government capacity, and District 13 physical condition, there are three approaches that can be implemented and adopted for improvement of informal settlement in District 13 of Kabul, which is settlement upgrading, the land readjustment, and urban redevelopment.
\end{abstract}

Keywords: informal settlement, sustainable neighborhood, approaches, District 13 of Kabul Afghanistan

\section{Introduction}

Afghanistan witnessed rapid urbanization in recent decades due to the post-war recovery process. When the war ended in 2001 with the fall of Taliban regime, most Afghan refugees returned to urban areas of Afghanistan, especially in Kabul. Moreover, the rapid urbanization, migration from rural areas, and population growth impacted Kabul with the manifestation of informal settlement (Bertaud, 2005).

In terms of Kabul, informal settlement refers to (a) the housing and settlements that were built up in violation of the master plan of Kabul, (b) settlements that developed without meeting the formal requirement for access to the land (Bismil, 2014).

Although the informal settlements serve a critical function in Kabul, the informal settlements are not without problems (Bertaud, 2005). The physical problems of informal settlements are enormous and pose severe challenges to informal residents in Kabul. In Kabul, the problems of informal settlements refer to lack of drainage system and sewage system, lack of solid waste management, unpaved and narrow streets, lack of open spaces, recreation and greenery, lack of water supply system, and pollution of underground water (Fazli, 2016; Nazire, 2016). Also, in most cases, property rights violations lead to insecurity of land tenure, which is another challenge because the illegal land grabbing without official permission is a threat of eviction and displacement (Nazire \& Kita, 2016).

With all the above, residents of informal settlements suffer social, spatial, and economic exclusion from the benefits and opportunities of the urban environment. In addition, the residents of informal settlements experience disadvantages such as geographical marginalization, shortage of basic infrastructure, improper governance framework, vulnerability due to the effect of poor environment, and natural disaster (Gebremedhin,2005). Recent researches have been conducted to identify the problems of informal settlements and the factors behind the growth 
of informal settlements in Kabul. However, based on the previous researches, it was found that there no researches and studies have been conducted to investigate the identification of approaches to address the problems of informal settlements. Therefore, this research covers the content and the subject missed by similar previous research.

Kabul Municipality Areas have been divided into 22 informal settlement Districts, which differ in size and other characteristics from District to District (Habib, 2011). Every District of Kabul can be studied for this research. However, District 13 has been chosen for this research because the physical problems which have been posed by informal settlement in that District of Kabul are most prominent and influential.

\section{Literature Review}

\subsection{Approaches to Addressing the Problems of Informal Settlement}

There are many approaches to address the problems of informal settlement. Those are core housing, provision of site-and-service, settlement upgrading, greenfield development, infill development, land readjustment, on-site redevelopment of informal settlement, and evacuation and relocation of informal settlement (Ackelman \& Andersson, 2008; Nassar et al., 2017).

Core housing refers to the provision of basic infrastructure for the dwellings with a minimum level of services. According to this approach, if finance becomes available, the housing should be extended (Ackelman \& Andersson, 2008). In addition, this approach includes the regulation of land tenure as well as the minimum provision of basic services, such as the provision of water supply, sanitation, and some other services (Ackelman \& Andersson, 2008).

Provision of site-and-services refers to an approach in which the residents get the plot and the primary services such as the sanitation, water supply system, and paved roads, which also ensure the land property right (Nassar et al., 2017). This approach includes the provision of site and services which are left for the house owners to construct (Nassar et al., 2017).

Settlement upgrading refers to the provision of basic services such as water supply, sewage and drainage systems, paving the streets, and provision of public amenities in the informal settlements, and this approach ensures land tenure (Khalifa, 2015). Based on this approach, houses are accepted as they had already been built; however, in some cases, rebuilt dwellings are also acceptable. Settlement upgrading improves the informal settlement without the relocation and settlement clearance (Khalifa, 2015).

Infill development, in common language, is associated with densification, and in terms of informal settlement refers to the development of vacant parcels within previously built areas (Ackelman \& Andersson, 2008). These areas are already served by public infrastructures, such as transportation, water, water supply system, and other utilities. On a large scale, the infill development is similar to greenfield development, but it has a distinct variation in that greenfield development requires more new infrastructure and basic services than the infill development (Ackelman \& Andersson, 2008). Indeed, infill development is building houses, business facilities, and public facilities on unused and underutilized land within existing urban areas. Moreover, infill development keeps resources where people live and allows rebuilding to occur (Ackelman \& Andersson, 2008).

On-site redevelopment of informal settlement targets the informal settlement where the housing conditions are highly deteriorated and unsafe (Nassar et al., 2017). This approach includes complete replacement of the physical fabric through gradual demolition and in-site construction of alternative housing (Nassar et al., 2017). This approach respects the legal right of residents for alternative housing and the dependence of their livelihood on staying in the same location in the city (Nassar et al., 2017).

The land readjustment is a technique based on the re-assembling of land parcels by a new layout plan together with the development of new urban infrastructures by means of changing shapes and conditions of land parcels, and construction of public facilities to increase the utility of sites and improve the public facility (Nagamine, 1986). The land readjustment technique combines several tools, including pooling of property rights, physical reorganization of land parcels, and preparation of a layout plan. All the tools mentioned above are used to provide planned urban areas and access to infrastructure (Nagamine, 1986). The area which is selected for a land readjustment project, their shapes, and conditions of sites within the project area will be improved by combining, dividing, annexing, and replotting (Nagamine, 1986).

Evacuation and relocation of informal settlement is the last option after all feasible approaches have been exhausted. This approach does not only include the complete demolition, but it also addresses the relocation of the residents. In this approach, residents are not going to stay in the same location, and must therefore move to a new city or fringe zones of the city (Nassar et al., 2017).

\section{Research methodology}




\subsection{Study Area}

Afghanistan is located in Central Asia. A landlocked and mountainous country covering an area of $652000 \mathrm{~km} 2$, Afghanistan shares a border with Iran in the West, Pakistan, in East and South and Central Asian countries such as Tajikistan, Uzbekistan, and Turkmenistan in the North. Afghanistan is the 41st largest country in terms of land area. Afghanistan has 34 provinces, and each province is divided into cities, districts, and villages (JICA, 2011).

Kabul, located in Kabul province, is the capital and largest city in Afghanistan. Kabul Municipality Areas includes 22 Districts, with areas of 103049 Hectares and approximately 396095 dwellings (JICA et al., 2011). Districts 13, located in western part of Kabul, makes the whole Kabul boundary, extending Southward to the mountain areas and constitutes the city boundary. To the North is District 5 located and to the East is District 6. Figure 1 shows Kabul Metropolitan Areas.

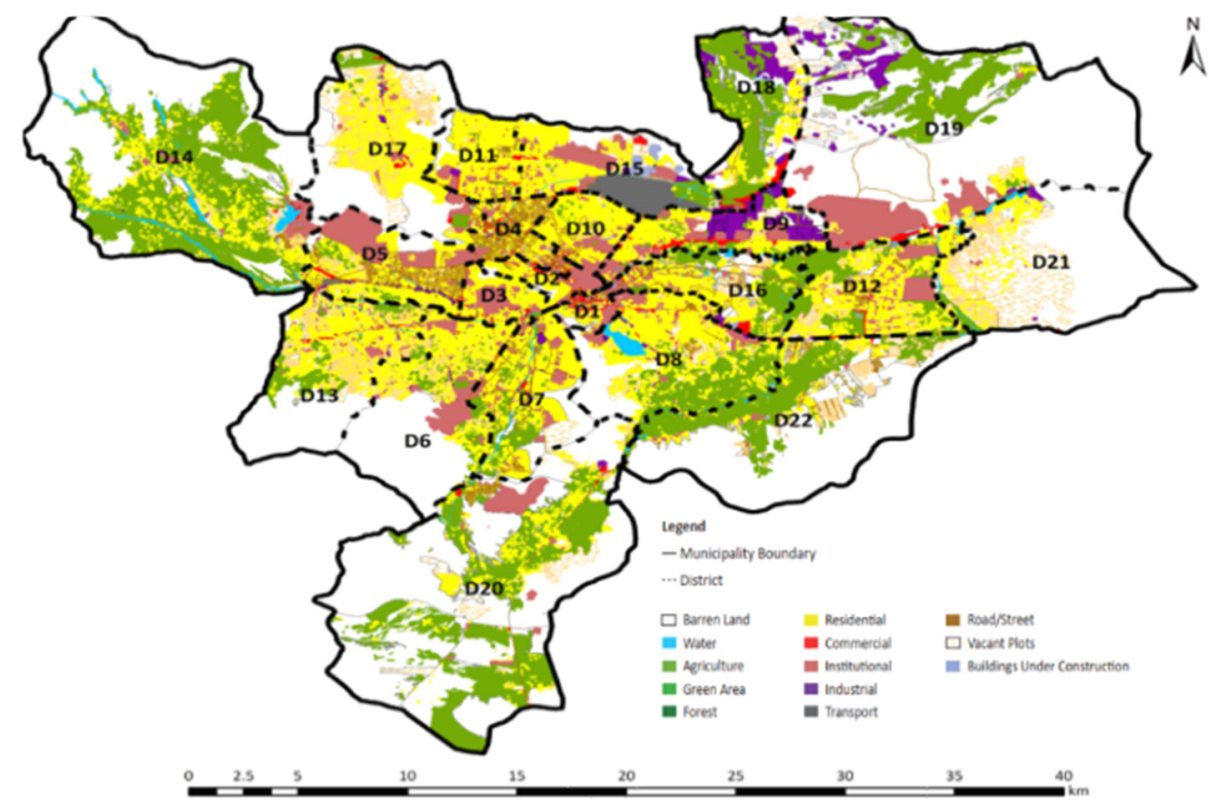

Figure 1. Kabul Metropolitan Areas. Source: MUDH et al. (2015)

\subsection{Methodology}

The research method for this paper is the empirical mix mode research method, which encompasses the qualitative and quantitative data collection based on primary data and secondary data. Prior to the field survey, secondary data has been obtained through reviewing different books, dissertation, Master Thesis, Ph.D. Thesis, Journals, Research Report, Government Constitution, Seminar Papers, Government Guideline, and Regulation on Registration of Urban Informal Properties. This secondary data has been reviewed to obtain a better understanding of approaches for improvement of informal settlement and to better understand the government policy vis a vis informal settlements.

Site observation, which is the first stage of primary data collection, is conducted to have a better understanding of informal settlement's physical condition, and problems of informal settlement with the aim to propose the proper approaches. The site observation was conducted from 4th January to 15th February 2019 in different parts of the case study area of District 13 in Kabul. In site observation, the main focus was on evaluating the physical and built environmental condition of informal settlement, which includes the physical measurement of the streets, exploring the housing quality and condition, provision level of public facilities, basic services, and infrastructure, open spaces, and greenery.

Following the site observation, the semi-structured interview has been used as an instrument in data collection. When conducting semi-structured interview, the respondents need to answer preset open-ended questions (Bird, 2009; Azila 2015). The interview has been conducted to have a deep understanding of the approaches to address the problems of informal settlement, in addition to having a clear view of the government policy toward informal settlement. The selection of interviewees was based on experience and skills in the urban planning field. 
The interview has been conducted with officials from Ministry of Urban Development and Land, Kabul Municipality, Capital Region Independent Development Authority (CRIDA), Directorate of District 13, JICA (Japan International Cooperation Agency), and UN-Habitat. From the Ministry of Development and Land, the interview has been conducted with the director of Urban Research and Development Center, director of Upgrading of Unplanned Settlement Directorate, and National Urban Advisor. From the Kabul Municipality, the interview has been conducted with the head and members of Land Readjustment and Urban Redevelopment Division Directorate of Design and Implementation of City Plan. Moreover, from the Capital Region Independent Development Authority (CRIDA), the interview has been conducted with the director of Technical Planning and members of the Upgrading and Renovation Program Division. From Directorate of District 13, the interview has been conducted with the director of the Directorate of District 13 and head of Engineering Division. An additional interview has been conducted with the members of the JICA Project Team (The Project for Development Service for Land Readjustment and Urban Redevelopment for Kabul Municipality). Moreover, the interview has been conducted with the members of UN-Habitat-Afghanistan. Table 1 shows the interviewee's position.

Table 1. Interviewee's position

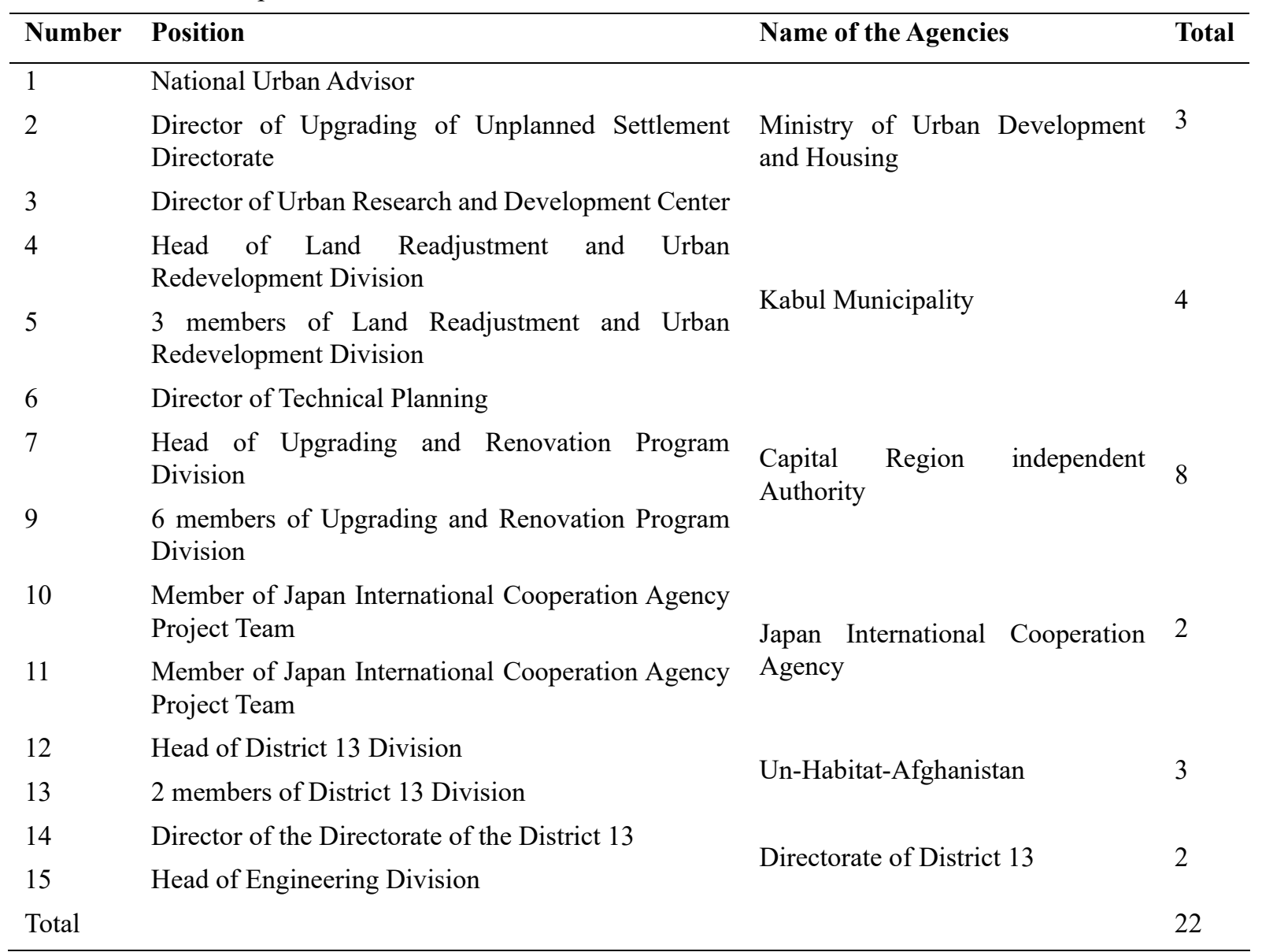

Furthermore, survey questionnaires have been used as an instrument in data collection. The survey questionnaire has been conducted with 200 residents of District 13 to have a better understanding of their challenges, physical problems, and agreement on approaches for changing the built form of their neighborhoods. The questionnaires have been prepared based on information gathered through the secondary data and interview. The Likert scale has been used to rank the agreement of respondents on approaches for changing the built form of their neighborhoods. Likert scale is a psychometric response scale in the questionnaire to obtain the respondent's preferences or degree of agreement and disagreement with a statement (Azial, 2015). On Likert scales, the participants are given the option to indicate their level of agreement or disagreement with a specific statement by way of an ordinal scale (Azial, 2015). The Likert scale mostly occurs in 5-point scale, which includes strongly agree, agree, neutral, disagree, and strongly disagree (Azial, 2015). However, the variability of the Likert scale relates to the aim of the 
research, and some researchers want to ensure the validity and reliability of the research and use the 7 and 9-point scale, and some researchers use 3-point scale. However, 5-point scale is the most prevalent rating on the Likert scale (Azial, 2015). Therefore, in this research, the 5 point Likert scale has been used.

Following the data collection, the gathered data have been taken under the process of examining, summarizing, and drawing conclusion. The data analysis includes two steps, qualitative data analysis (interview) and quantitative data analysis (questionnaire survey).

The qualitative data analysis includes the analysis of the data that has been obtained through the interview. In the interview, the data has been collected in the form of notes, Word texts, and transcripts, which include the description and explanation of distributed open-ended questions. This analysis aims to extract relevant information from the gathered data. Two approaches can be used to analyze the qualitative data, which are the deductive approach and the inductive approach (Burnard et al., 2008). The deductive approach includes using the predetermined framework to analyze the data, and the researchers use their structure on the gathered data to analyze the interview transcript (Burnard et al., 2008; Jamshid, 2014). In contrast, the inductive approach consists of analyzing of the data without predetermined theory and structure (Burnard et al., 2008). This approach is suitable where little is known about the study phenomenon, and is the most common method for the qualitative data analysis (Burnard et al., 2008; Jamshid, 2014). Different inductive approaches are available to analyze the qualitative data, but the most common is the content analysis and narrative analysis (Burnard et al., 2008). However, for this research, content analysis has been used. The content analysis includes different steps such as becoming familiar with the data, coding and labeling the transcript, creation of categories (themes) by bringing several codes together, defining and naming the themes, and writing up the result (Burnard et al., 2008). In this research, first, the interview transcript has been read carefully, the informal settlement relevant words, sentences, phrases, and sections have been labeled and coded. The coded and labeled data which is relevant to the approaches to address the informal settlement problems have been highlighted.

The quantitative data analysis includes the analysis of the data that has been obtained through the survey questionnaires. In qualitative data analysis, the data is analyzed statistically (Azila, 2015). This analysis aims to measure the resident's agreement on approaches for changing the built form of their neighborhoods in District 13 of Kabul. In this research, Frequency Analysis has been used to analyze quantitative data. The results have been tabulated in the form of frequency number and percentage according to the total respondents. The findings are then shown in diagram form for better understanding. Based on Azila (2015), the formula for the Frequency analysis is:

$$
\text { Percentage } \%=n / N * 100
$$

Equation (1) is Frequency Analysis equation, where $n=$ is the number of respondents who respond with the same answer toward statement, $\mathrm{N}=$ is the total number of respondents who have participated in the research

The last stage of this research is the conclusion and recommendation. The framework of solution and recommendation is based on the finding and results have been suggested on improving informal settlement in District 13 of Kabul.

\section{Result and Finding}

This section of research presents the finding and results which have been obtained through interview and survey questionnaire.

\subsection{Key Finding of Interview}

The critical finding of the interview includes approaches to address informal settlement problems in District 13 of Kabul, since the entire District 13 developed informally. Most of the interviewees believe that it is not applicable to redevelop informal sentiments through the total clearance of informal settlements. For example, interviewee 1 (Table 1) indicates that "there are different approaches for the improvement of informal settlement, but it is important that the approaches should answer the needs and necessities of area. Then, land readjustment and urban redevelopment can perform a vital role in the improvement of informal settlement in District 13. Moreover, the settlement upgrading also has an important role in the improvement of informal settlement according to District 13 physical condition".

Interviewee 3 indicates that "the Kabul municipality implements two approaches to address the problems of informal settlements, settlement upgrading, and land readjustment projects. Based on the fiscal year work, Kabul municipality upgrades unplanned areas in Kabul. Also, the land readjustment approach is ongoing only in Kabul supported by JICA (Japan). Besides, settlement upgrading is the other approach that can be used for the improvement of District 13. Ministry of Urban Development and Land is a policymaker authority, which covers 
all cities around Afghanistan, Upgrading of Unplanned Settlement Directorate is preparing the policy and put the implementation of policy on the stand of respective municipalities".

Based on Interviewee 4 "for improvement of District 13, the Urban Authority can adopt the two-track strategy. First, preventive, not allowing other construction and housing development. Second lucrative, using redevelopment project by land readjustment, and urban redevelopment and housing progress."

Interviewee 10 indicates that "upgrading through different international organizations like UN-habitat and World Bank implemented for the improvement of the informal settlement in Kabul. This usually does not bring much changes in the structure of a neighborhood, since it just includes improvement of the basic infrastructure like paving the streets and providing the drainage system. Most of the residents were satisfied with the upgrading approach, however in some informal areas, upgrading may not be applicable, or it will not bring much changes. Therefore, it was recommended that those areas should be improved through other development approaches, like land readjustment and urban redevelopment."

Interviewee 11 states that "when the development agency is preparing the improvement plans, the participation of the community should be considered to get knowledge about the people who live at the site. It is important to involve communities, to make a successful improvement plan, and to understand their needs."

According to interviewee 12 "UN-Habitat working on the upgrading of the areas with high population density and the areas where the poor residents live. This upgrading includes the paving of the street, the development of the drainage system and sewage system. The upgrading aims to increase, sense of belonging among people and the relationship between people and government by community involvement in the implementation of the projects".

Based on interviewee 14 "Land readjustment, urban redevelopment, and upgrading currently, have been taking in to account for the improvement of District 13. In addition, along the Qorogh mountain, if the site be considered for resettlement, it will help to reduce the problem of the informal settlement in District 13."

Most interviewees indicate that the land tenure problems and physical problems of the informal settlement must be addressed at the same time and parallel. Therefore, for the legalization of informal settlement, a Regulation on Registration of Urban Informal Properties has been prepared by Land Independent Authority and approved by the Afghanistan Cabinet in December 2017. Moreover, concluding form the interview, for addressing the physical problems of informal settlement, there are three approaches. First upgrading informal settlement with-stand of Ministry of Urban Development and Land, second land readjustment with-stand of Kabul Municipality, and third urban redevelopment with-stand of Kabul Municipality. To have a better understanding of the Regulation mentioned above and approaches, government policy is needed to be reviewed.

\subsection{Policy Review in Addressing Land Tenure Issue}

For addressing the land tenure issue in Kabul, Land Independent Authority has prepared Regulation on Registration of Urban Informal Properties which has been approved by Afghanistan Cabinet in December 2017. Article 1 of this Regulation indicates that this Regulation is based on Article 112 of the Land Management Law. Article 112 of the Land Management Law indicates that "Matters relating to the provision of security of tenure for individuals residing on informal urban land. Including the survey and registration of the land and the issuance of documentation to individuals residing on the land shall be regulated by the Afghanistan Independent Land Authority with cooperation from the Kabul Municipality, and other respective municipalities and agencies in accordance with a separate Regulation."

Based on Article 2 of this Regulation "the main objective of this Regulation is to administrate the land survey process and registration of properties in the informal urban settlement. Furthermore, providing tenure security for the occupants of properties in informal urban settlement". Based on Article 4 of this Regulation, "Arazi (Land Independent Authority) is responsible for the implementation of this Regulation in cooperation with other relevant public agencies." Article 5 of this Regulation indicates that the Arazi (Land Independent Authority) in collaboration with Ministry of Urban Development and Housing, Independent Directorate for Local Governance and Municipalities will identify the residential houses which are built in the informal settlements for registration and granting of occupancy certificates to the occupants according to the following conditions:

1) The property should be within the boundaries of the master plan and urban strategic plan.

2) The property should not locate within a water source area.

3) The property should not locate in public service establishments, entertainment parks, sports grounds, green areas, and protectable area.

4) The property should not be in an area that is planned for the development of government or public projects 
within a period of ten years.

For the registration and granting of property deeds, Article 8 of this Regulation indicates that:

1) Arazi (Land independent Authority) shall register the residential houses, business places, public service establishments, empty land parcels, and protected areas located within the boundary of informal settlements.

2) Occupancy certificates will be granted only to occupants of residential houses in informal settlements.

3) The occupancy certificates mentioned above will be granted based on the following terms. The occupant should be a real person. The building should be used only for residential and shelter purposes. There is no conflict among the shareholders and descendants of the property.

4) If there is a conflict involving the property, the property will be registered after solving the conflict.

An issue which arises is the status of a residential house developed on governmental or state land and the property is occupying state land. Article 9 of this Regulation addresses this issue as the following:

1) If a property in an informal settlement is on state land, only $300 \mathrm{~m} 2$ will be registered in the name of the occupant or his/her descendant.

2) If a property in an informal settlement is on state land, any additional area from $300 \mathrm{~m} 2$ up to $500 \mathrm{~m} 2$ that is not required by the state can be sold to the occupant based on a just and fair price considering the location of the land.

3) If a property in an informal settlement is on state land, any additional area from $500 \mathrm{~m} 2$ up to $1000 \mathrm{~m} 2$ that is not required by the state can be sold to the occupant at the prevailing market price and considering the location of the land.

4) If a property in an informal settlement is on state land, any additional area exceeding $1000 \mathrm{~m} 2$ will be repossessed by the state from the occupant or his/her descendants.

In terms of registration and issuing of the occupancy certificate, based on Article 11 of this Regulation:

1) The occupancy certificate is issued at the price of 1000 Afs (Afghanis currency) for the property occupants (man or woman).

2) Arazi (Land Independent Authority) will register and save the occupancy certificate, which contains all information on the characteristics of the property in a database.

3) The occupancy certificate is prepared in three copies, one belonging to the occupant, the second to the municipal district office, and the third to the Arazi (Land Independent Authority) office.

4) The municipal district office is responsible for sending a copy of the occupancy certificate mentioned in section 3 to the municipality.

Preparation of the occupancy certificate is the responsibility of Arazi (Land independent Authority). Article 17 of the Regulation states that "the Arazi (Land independent Authority) will prepare the form and contents of the occupancy certificates. In addition, Arazi (Land independent Authority) and other relevant agencies must conduct public awareness campaigns for the occupants of informal settlements through radio, television, and other mass media". After issuing the occupancy certificate, Arazi (Land independent Authority) will sign a contract with the occupants of informal urban settlements. The contract will specify the responsibilities of the occupants. According to article 10 of the Regulation the owner of an occupancy certificate must pay the annual Safayi (Clearance) fees to the municipality's bank account.

District 13 of Kabul is located within the boundary of the Kabul Master Plan. 70\% of the respondents responded that they have their own houses and are the owners of the houses in which they live, while $30 \%$ of respondents indicated that they rented the houses in which they live. According to Article 8 of the Regulation on Registration of Urban Informal Properties, the occupancy certificate will be granted only to occupants of residential houses in informal settlements. Then, occupants of property who live in District 13 are eligible to apply for the occupancy certificate. Residents of District 13 who rent the houses are not eligible to apply for an occupancy certificate. The solution is that property owners of the rented houses apply for the occupancy certificate. Figure 2 shows the housing ownership in District 13 of Kabul. 


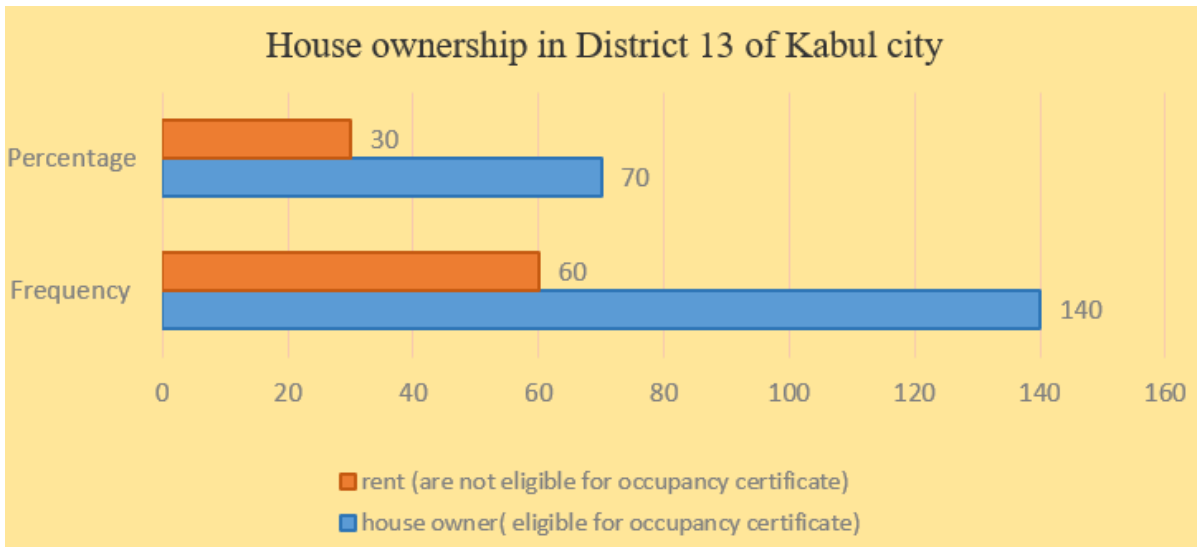

Figure 2. Housing ownership in District 13 of Kabul. Source: Field survey (2019)

Moreover, to capitalize on the well planned, well-financed urbanization, the Government of Afghanistan, with technical assistance from UN-Habitat, is implementing an innovative program to address urban governance in Kabul and eleven other cities under the name of City for All. Based on interview with member of UN-Habitat, the City for All program is supporting Afghan municipalities to survey and register all properties (estimated 500,000 properties in Kabul and 500,000 properties in eleven other cities) to provide technical assistance to Arazi (Land Independent Authority) to issue occupancy certificate in informal urban areas to enhance tenure security for urban residents. According to City for All program, the households in Kabul, including District 13, will receive an occupancy certificate guaranteeing their right to stay on their property without the threat of eviction. The legal framework for City for All program is Regulation on Registration of Urban Informal Properties. Therefore, by this Regulation and City for All Program, the land tenure issue addresses in District 13 of Kabul.

\subsection{Policy Review in Addressing Physical Problems}

There are three approaches to address the physical problems of the informal settlement in Kabul, including the land readjustment and urban redevelopment with support of Kabul Municipality, and settlement upgrading with support of Ministry of Urban Development and Land. Based on interviewee 1 (Table 1), Ministry of Urban Development and Land is a policymaker authority, which covers all cities around Afghanistan. Upgrading of Unplanned Settlement Directorate is preparing the policy and put the implementation on the stand of respective municipalities. In addition to the Ministry of Urban Development and Land and Kabul Municipality, Capital Region Independent Authority is in charge of providing the public facilities for the capital region of Afghanistan.

\subsubsection{Land Readjustment}

Based on the interview with the officials from Kabul Municipality, the land readjustment is being used to reshape and reassemble the land parcel in Kabul. According to land readjustment by the participation of people, the public facilities and basic services are to be created in the urban areas, or the existing facilities will be improved to increase the utility of the urban areas. To plan and implement the land readjustment project in Kabul, Kabul Municipality prepared the Procedure on Land Readjustment and Urban Redevelopment which was approved by Afghan Cabinet on 8 February 2017 [Interviewees 4,5].

The land contribution rate is based on required land for the provision of public amenities, recreation areas, widening of the streets, bank land, and financial land. Based on this procedure the maximum rate of contribution is not exceeding $40 \%$ of the size of the housing plot. The owners of properties are required to contribute the required land for the provision of infrastructure and public amenities through the contribution rate.

According to this procedure financial land is the specific land that will deduct from the contributed land to finance the project and services costs, and bank land is the storage and accumulation of land plots during the land readjustment process. The Municipality can sell it to finance the expansion expenditure of the project or it can be used for urban expansion and urban development later. The bank land is $10 \%$ of total areas.

\subsubsection{Urban Redevelopment}

Based on the interview with the official from Kabul Municipality, the urban redevelopment project includes the conversion of the property right from land to the apartment with consideration of the land value and land location. In this case, a number of apartments are to be sold to provide the budget and project cost, including apartment 
construction cost, basic services cost, and other requirements of the project. According to Procedure on Land Readjustment and Urban Redevelopment, (2017 urban redevelopment project can be implemented on the property with the following condition:

1) In the master plan, the target area is considered to have medium and high population density.

2) The property located in areas with public buildings and streets are considered for development. Then, for the owners of the property in suitable areas, the apartments build to exchange the property to an apartment.

Based Procedure on Land Readjustment and Urban Redevelopment, (2017) urban redevelopment in Kabul includes the conversion of $40-70 \%$ of the property to apartment according to valuation and location of each property and its measurement to conversion to the apartment with agreement and consent of property owners and Kabul Municipality. The remaining land will be sold to finance apartment construction cost, basic services cost, and other requirements of the project. If the converted land is smaller than the apartment areas, then the property owners are required to buy the remaining area of the apartment according to the Municipality's price of consideration. If the converted land is more than one apartment or several apartment areas, the additional land, according to Municipality's price of consideration with the agreement of landowners, will be sold to pay for the landowner.

In the urban redevelopment process, temporary and permanent resettlement is an inevitable action. Also, in urban redevelopment planning, the Kabul Municipality intends to keep the residents in existing areas by using the barren land for construction of new residential apartments. In the case of temporary resettlement, the following two alternatives are available for Kabul Municipality to settle the displaced residents up to the completion of the project. First, transfer of residents to residential buildings that are the property of Kabul Municipality or the residential buildings, which are the property of the Afghan government and coordinated by Kabul Municipality. Second, receiving the funds from the Ministry of Finance by the Municipality to hire or rent residential houses in the area inside the city for displaced people by taking into consideration the life quality of the residents.

\subsubsection{Settlement Upgrading}

Based on [interviewees 2,4] upgrading of the urban area is a multi-sectoral operation that integrates environmental, economic, and social intervention. These interventions include the provision of urban services and the guarantee of land tenure. To manage the settlement upgrading, the Ministry of Urban Planning and Land prepared the Policy on Upgrading and Redevelopment of informal settlement [interviewee 2,4]. This Policy on the Upgrading of Informal Settlements is responding to Article 14 of the Afghanistan Constitution, which indicates: "the state shall adopt necessary measures for provision of housing and distribution of public estates to deserving citizens in accordance with the provisions of law and within financial possibilities."

Based on the interviewees from the Ministry of Urban Development and Land by taking into consideration the high percentage of the informal settlement in Afghanistan, particularly in Kabul, it is not feasible to relocate and redevelop them through complete clearance. Thus a practical solution would be to regularize and upgrade these settlements in a systematic manner and convert them into the formal urban fabric. The Policy on Upgrading of Informal Settlement aims to provide a framework and policy guidance to integrate informal settlement as part of the urban fabric. The main objective and aims of the policy are:

1) To enable the delivery and extension of urban services in all informal settlements in Afghanistan,

2) To promote the incremental improvement of tenure security along the continuum of property rights,

3) To enhance and increase municipal revenue and levies through the delivery of basic services to the informal urban settlements,

4) To regularize informal urban settlements in an orderly manner.

The government of the Islamic Republic of Afghanistan implements and supervises the settlement upgrading through the Ministry of Urban Development and Land, the Independent Directorate for Local Government, and Municipalities. The Afghan government has established Urban Upgrading Directorate within the Ministry of Urban Development and Land to manage the settlement upgrading. In addition, Upgrading Directorate is responsible for coordinating between the Ministry and other relevant entities on settlement upgrading. The government of Afghanistan will assign resources from its development budget or seek external resources to upgrade informal settlement [Interviewee 1]. Furthermore, based on Policy on Upgrading of Informal Settlement, the following settlements have the settlement upgrading eligibility:

1) All settlements which are recognized eligible for occupancy certificate through Regulation on Registration of Urban Informal Properties. 
2) Older unplanned settlements, such as urban villages.

3) Grabbed private land is not eligible for upgrading until the courts resolve the property status to clear title.

4) A building or area designated as a historic building by the Ministry of Information Culture. Upgrading design must be done in consultation with that Ministry, and they will have the authority to limit upgrading procedures that may damage cultural resources.:

\subsection{Key Finding of Questionnaire Survey}

For the implementation of the land readjustment and land rearrangement in settlement upgrading, the landowners are required to distribute part of their land. Thus, this research aims to identify the agreement of the landowners on land distribution for the improvement of their settlements.

Figure 2 shows that $30 \%$ of the respondents are not the owner of the property. Thus, they do not have the authority of land distribution. Of the $70 \%$ of the respondents who are the owners of the property, $8.5 \%$ of them disagree on land distribution, and $91.5 \%$ of them agree on land distribution. Figure 3 shows the agreement of residents on land distribution.

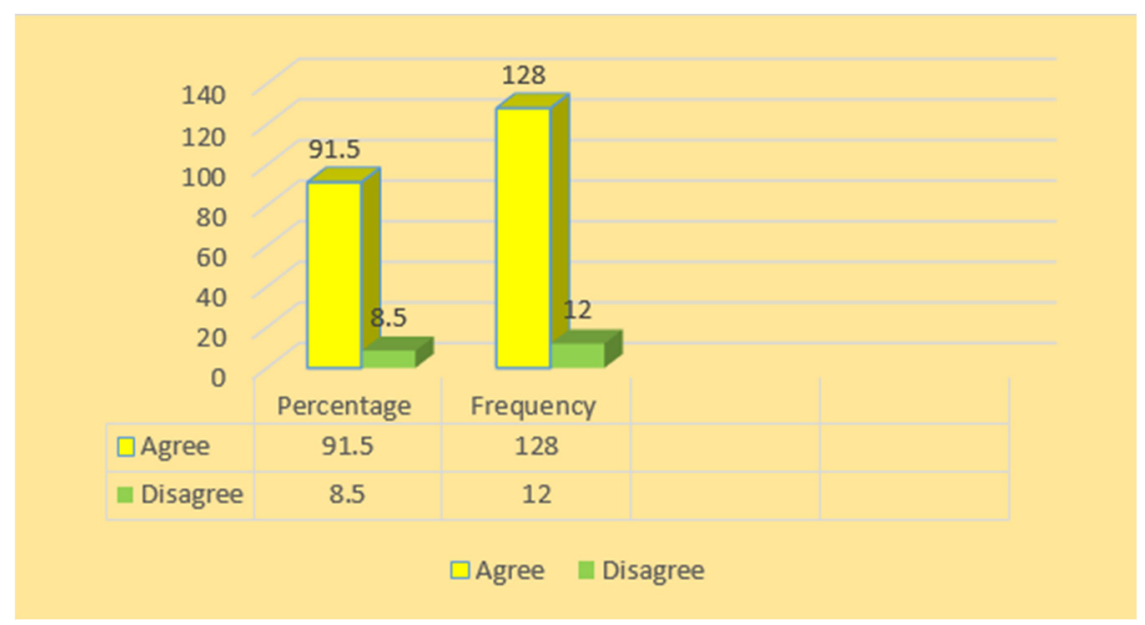

Figure 3. Agreement of residents on land distribution. Source: Field survey (2019)

Based on the interview, it has been found that there are three approaches (urban redevelopment, land readjustment, and settlement upgrading) to improve informal settlement in Kabul. However, this research aims to examine these approaches from the perception of the residents of District 13. Table 2 shows the preferences of residents on approaches for improvement of the informal settlement in District 13 of Kabul.

Table 2. Preferences of residents on approaches for improvement of informal settlement in District 13 of Kabul

\begin{tabular}{lllllll}
\hline No & Approaches & Likert Scale & & & \\
\cline { 3 - 6 } $\mathbf{1}$ & Settlement upgrading & 113 & Agree & Neutral & Disagree & Strongly disagree \\
& & $56.5 \%$ & $34.5 \%$ & 7 & 11 & 0 \\
$\mathbf{2}$ & \multirow{2}{*}{ Land readjustment } & 71 & 90 & 12 & $6.5 \%$ & $0 \%$ \\
& & $35.5 \%$ & $45 \%$ & $6 \%$ & $8.5 \%$ & $5 \%$ \\
$\mathbf{3}$ & \multirow{2}{*}{ Urban redevelopment } & 31 & 44 & 21 & 88 & 16 \\
& & $15.5 \%$ & $22 \%$ & $10.5 \%$ & $44 \%$ & $8 \%$ \\
\hline
\end{tabular}

Table 2 shows that $56.5 \%$ of the respondents strongly agree, and $34.5 \%$ of the respondents agree with the settlement upgrading. Also, $35.5 \%$ of the respondents strongly agree, and $45 \%$ of the respondents agree with the land readjustment. On the other hand, $44 \%$ of the respondents disagree, and $8 \%$ of the respondents strongly disagree 
with the urban redevelopment approach. Therefore, based on the preference of residents, the settlement upgrading and land readjustment are the proper approaches to improve the informal settlement in District 13 of Kabul.

\section{Discussion}

Three approaches can improve the informal settlement in District 13 of Kabul. First, settlement upgrading is one of the approaches that can improve the informal settlements in District 13 of Kabul. Article 5 of Regulation on Registration of Urban Informal Properties indicates that the properties located within the boundary of the master plan are eligible to be included in the upgrading program.

Because District 13 of Kabul is located within the boundary of the master plan, it is eligible for upgrading. The residents of District 13 prefer this approach for improvement of their settlement (Table 2). Moreover, its implementation is much more comfortable in comparison to the other two approaches. Also, it is not such a complicated approach, as a land readjustment approach, and costs less than an urban redevelopment approach. Thus, this approach can be the first option for improvement of the informal settlement in District 13 of Kabul.

Second, land readjustment can also be an improvement approach for improvement of District 13, which is applicable within the boundary of the master plan of the Kabul. Findings indicate that $91.5 \%$ of the respondents agree to give part of their land for improvement of their settlements (Figure 3), suggesting that he land readjustment approach is applicable for the improvement of the informal settlement in District 13. However, this approach requires government leadership to manage the land readjustment process and land distribution, which is troublesome because the most influential factor behind the growth of informal settlement is the limited capacity of government (Bismill, 2014). Thus, this approach has its difficulties. Moreover, Table 2 shows that, in contrast to land readjustment, the residents of District 13 prefer the settlement upgrading approach. Thus, the land readjustment approach can be the second option for the improvement of the informal settlement in District 13 of Kabul.

Urban redevelopment is another approach to improve the informal settlement in District 13 of Kabul. This approach is applicable in the areas with medium and high population density in the master plan. However, most of District 13 is considered as low population density areas in the master plan (See Figure 4). Thus, this approach is not applicable in the most of District 13. Furthermore, Table 2 shows the majority of the respondents disagree with the urban redevelopment approach. Moreover, this approach is costlier in comparison to the other two approaches. Although the conversion of land to the apartment finances the construction costs, the construction of the apartments will take time. In addition, the municipality must provide for displaced people until the project is completed. This will add more cost to the urban redevelopment approach and requires good government leadership. However, during the field survey, some respondents indicated that this approach could be the improvement approach for areas with low-quality housing, which will replace the low-quality houses with high-quality apartments. Therefore, this approach can be the last option for the improvement of an informal settlement in District 13 of Kabul.

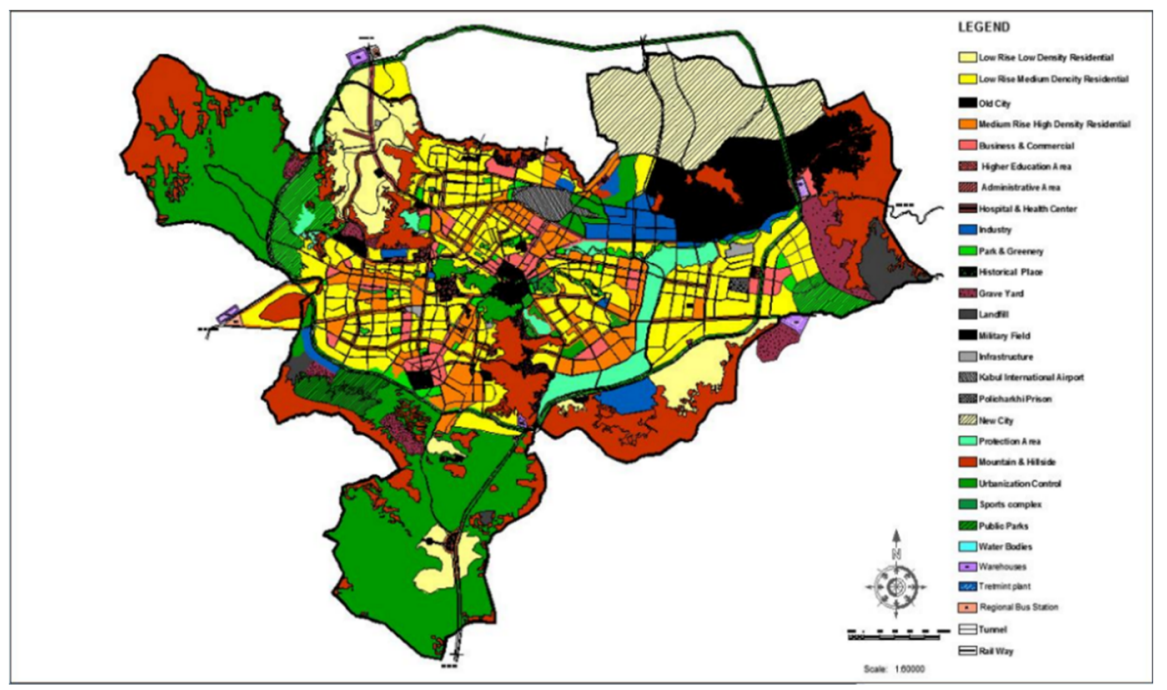

Figure 4. Kabul Master Plan. Source: https://km.gov.af 
The informal settlement differs in size and other characteristics from District to District, and this research has been done based on the perception of residents of District 13 of Kabul (Kabul Municipality Areas includes 22 Districts). Thus, the finding of this research may not be implementable in other Districts of Kabul. The study can be expanded to investigate other Districts of Kabul.

In addition, for the implementation of each approach, the financial capacity of the Urban Authority is vital. The evaluation of the financial capacity of the Afghan Urban Authority was not considered in this research. Therefore, further research is needed to examine the financial capacity of the Afghan Urban Authority.

Moreover, to have a better understanding of the identification of the proper approach for improvement of informal settlements, it is crucial to have a better understanding of the needs, preferences, and demands of residents. Therefore, further research is needed to cover the needs and demands of residents.

\section{Conclusion}

Afghanistan witnessed rapid urbanization in recent decades due to the post-war recovery process. When the war ended in 2001 with the fall of the Taliban regime, most Afghan refugees returned to urban areas of Afghanistan, especially in Kabul. Moreover, the rapid urbanization, migration from rural areas, and population growth impacted on Kabul with the manifestation of informal settlement. Informal settlements are not without problems; the physical problems of the informal settlement are considered enormous challenges for informal residents. Therefore, this paper investigates the approaches to address informal settlement problems.

The legal framework to address the land tenure issue is the Regulation on Registration of Urban Informal Properties. Based on this Regulation, Arazi (Land Independent Authority), in collaboration with the Ministry of Urban Development and Land, Independent Directorate for Local Governance and Municipalities will identify the residential houses which are built in the informal settlements for registration and granting of occupancy certificate which addresses the land tenure issue. On the other hand, three approaches can improve the informal settlement in District 13 of Kabul. The finding of this research indicates that, according to the resident's preference and District 13 physical condition, these approaches are, in order of preference, settlement upgrading, the land readjustment, and urban redevelopment.

This research will help the Afghan Urban Authority in choosing the proper approaches for improvement of District 13 according to its physical conditions and the preferences of residents. Furthermore, this research increases the awareness of residents towards their settlements, which will encourage them to feel more responsible for their environment and will encourage them to apply for an occupancy certificate.

However, this research is not without limitations. First, the data has been gathered through survey questionnaires and interviews. Therefore, because of unwillingness, the respondents might respond to the questions without thinking, thereby responding quickly and incorrectly. Second, the residents of informal areas do not have secure land tenure, and thus may not respond honestly. Third, insecurity has recently increased in the Districts 13 of Kabul. It was a challenge for researchers to make the site visit. Finally, the informal settlements differ in size and other characteristics from District to District. This research has been done based on the perception of residents of District 13 of Kabul. Thus, this research may not be applicable in other Districts of Kabul.

\section{Acknowledgments}

This paper is an output of a research project for the award of master of science (Urban and Regional Planning).

\section{References}

Ahmadi, A. S., \& Kajita, Y. (2017). Evaluation of urban land development direction in Kabul city, Afghanistan. International Journal of Urban and Civil Engineering, 11(2), 152-162.

Azila, H. (2015). Delay in settlement of final account. MSc Thesis, Universiti Teknologi Malaysia, Skudai, Johor Bahru, Johor Malaysia.

Abebe, F. K. (2011). Modeling informal settlement growth in Dar Es Salaam, Tanzania. MSc Thesis, University of Twente, the Netherlands.

Ackelman, H., \& Andersson, M. (2008). Methods to Solve the Problem of Informal Settlements, the Case of Hangberg, South Africa. MSc Thesis, Royal Institute of Technology, Stockholm, Sweden.

Abbott, J. (2002). An analysis of informal settlement upgrading and critique of existing methodological approaches. Habitat International, 26(3), 303-315. https://doi.org/10.1016/S0197-3975(01)00049-2

Bismill, R. A. (2014). Unperceptive Urban Growth: A case study on the growth of informal settlements of Kabul, Afghanistan. MSc Thesis, University of Birmingham, Birmingham. 
Bird, D. K. (2009). The use of questionnaire for acquiring information on public perception of natural hazards and risks mitigation. Copernicus Publications on behalf of the European Geosciences Union, 1307-1325. https://doi.org/10.5194/nhess-9-1307-2009

Burnard, P., Gill, P., Stewart, K., Treasure, E., \& Chadwick, B. (2008). Analyzing and presenting qualitative data. British Dental Journal, 204(8), 429-432. https://doi.org/10.1038/sj.bdj.2008.292

Bolay, J. (2006). Slums and urban development: questions on society and globalization. The European Journal of Development Research,18, 284-298. https://doi.org/10.1080/09578810600709492

Bertaud, A. (2005). Urban Land Management in Afghanistan Kabul Urban Development Current city structure, spatial issues, recommendations on urban planning. Kabul Report 2 with graphs. pp. 1-31. Retrieved fromhttp://alainbertaud.com/wpcontent/uploads/2013/06/AB_Kabul_Report_2-with graphs.pdf.

Burra, S. (2005). Towards a pro-poor framework for slum upgrading in Mumbai, India. Environment and Urbanization, 17(1), 67-88. https://doi.org/10.1630/0956247053633700

Choguill, C. L. (2007). The search for policies to support sustainable housing. Habitat International, 31, 143-149. https://doi.org/10.1016/j.habitatint.2006.12.001

Erman, T. (2001). The politics of squatter (Gecekondu) studies in Turkey: the changing representation of rural migrant in the academic discourse. Urban Studies, 38(7), 983-1002. https://doi.org/10.1080/0042098 0120051620

Fazli, M. (2016). Factors behind the Growth of Informal Settlements in Kabul. Institute of Urban and Spatial planning, Faulty of Architecture, the Slovak University of Technology in Bratislava. https://doi.org/ 10.13164/acau.fa2016.9

Galuska, J. (2014). Community-based approaches to settlement upgrading as manifested through the big ACCA projects in Metro Manila, Philippines. Environment and Urbanization, 26(1), 276-296. https://doi.org/ $10.1177 / 0956247813517850$

Green, R. A. (2008). Unauthorized development and seismic hazard vulnerability: a study of squatters and engineers in Istanbul, Turkey. Disasters, 32(3), 358-376.

Gebremedhin, Y. (2005). Preliminary Assessment of Informal Settlements in Kabul City. pp. 3-26. Retrieved from http://www.terrainstitute.org/pdf/Informal_settlement_yohannes.pdf.

Hegazy, I. R. (2016) Informal settlement upgrading policies in Egypt: towards improvement in the upgrading process. Journal of Urbanism, 9(3), 254-275. https://doi.org/10.1080/17549175.2015.1009845

Javid, A. H. (2013). A Study on Cooperative Land Development by Landowners in Afghanistan's Context Considering Land Readjustment as Case Study. MSc Thesis, University of Tokyo. Bunkyo, Tokyo, Japan.

Habib, J. (2011). Urban cohesiveness in Kabul City: challenges and threats. International Journal of Environmental Studies, 68(3), 363-371. https://doi.org/10.1080/00207233.2011.578338

Hasan, A. (2006). Orangi Pilot Project: The Expansion of Work beyond Orangi and the Mapping of Informal Settlements and Infrastructure. Environment and Urbanization, 18(2), 451-480. https://doi.org/10.1177/ 0956247806069626

Jamshid, S. (2014). Qualitative research method-interviewing and observation. Journal of Basic and Clinical Pharmacy, 5(4), 87-88. https://doi.org/10.4103/0976-0105.141942

JICA. (2011). Draft Kabul City Master Plan-Product of Technical Cooperation Project for Promotion of Kabul Metropolitan Area Development, Sub Project for Revise the Kabul City Master Plan.

JICA., KM., \& MUDH. (2011). Promotion of Kabul Metropolitan Area Development: Capacity Development Project, Kabul City Current Status Report for Urban Development.

Khalifa, M. A. (2015). Evolution of Informal Settlements Upgrading Strategies in Egypt: From Negligence to Participatory Development. Ain Shams Engineering Journal, 6(4), 1151-1159. https://doi.org/10.1016/j.asej. 2015.04.008

Lombard, M. (2014). Constructing Ordinary Places: Place-Making in Urban Informal Settlements in Mexico. Progress in Planning, 94(2014), 1-53. https://doi.org/10.1016/j.progress.2013.05.003

MUDH., K. M., \& Un-Habitat. (2016). Strategic Nahia Action Plan. District 13.

MUDH., K. M., \& IDLG. (2015). State of Afghan Cities. Volume 1(2015), Kabul Afghanistan. 
MUDH. (2011). Draft Upgrading Policy. Kabul Afghanistan.

Majale, M. (2008). Employment creation through participatory urban planning and slum upgrading: the case of Kitale, Kenya. Habitat International, 32, 270-282. https://doi.org/10.1016/j.habitatint.2007.08.005

Nassar, D, M., \& Elsayed H, G. (2017). From Informal Settlements to sustainable communities, Alexandria Engineering Journal. https://doi.org/ 10.1016/j.aej.2017.09.004.

Nazrire, H. (2016). A Study on Characteristics of Informal Settlements and Effects of Upgrading from Aspects of Houses, Land Acquisition, and Social Factors in Kabul City, Afghanistan. Ph.D. Thesis, Osaka University, Yamadaoka, Suita, Osaka.

Nazire, H., \& Kita, M. (2016). Specifying Characteristics of Informal Settlements by Comparing Four Areas from the Aspects of Houses, Land Tenure and Social Factors in Kabul, Afghanistan. Journal of Architecture and Planning, 81(728), 2197-2206. https://doi.org/10.3130/aija.81.2197

Nabizada, T. (2012). A Study on the Spatial Structure of Houses and Open Spaces by the Analysis of Physical Improvements and Daily Activities in the Typical Residential Areas in Kabul City. Ph.D. Thesis, Osaka University, Yamadaoka, Suita, Osaka.

Nijman, J. (2008). Against the odds: slum rehabilitation in neoliberal Mumbai. Cities, 25(2008), 73-85. https://doi.org/10.1016/j.cities.2008.01.003

Okyere, A. S., \& Kita, M. (2015). Rethinking urban informality and informal settlements growth in urban Africa: A literature discussion. Journal of Sustainable Development in Africa, 14(6), 101-121.

Procedure on Land Readjustment and Urban Redevelopment. (2017). Kabul Municipality. Kabul Afghanistan.

Regulation on Registration of Urban Informal Properties. (2017). Kabul, Afghanistan.

Ranjbar, A. S., \& Mizokami, S. (2015). Implementation of land readjustment process in Kabul Afghanistan. International Journal of Technical Research and Applications, 32(32), 37-41.

Un-Habitat, (2015). Habitat III Issue Papers 22-Informal Settlements; UN-Habitat: Nairobi, Kenya.

\section{Copyrights}

Copyright for this article is retained by the author(s), with first publication rights granted to the journal.

This is an open-access article distributed under the terms and conditions of the Creative Commons Attribution license (http://creativecommons.org/licenses/by/4.0/). 